\title{
Circulating miRNAs as Potential Biomarkers in Prostate Cancer Patients Undergoing Radiotherapy [Corrigendum]
}

Kachris S, Papadaki C, Rounis K, et al. Cancer Manag Res. 2021;13:8257-8271.

The authors have advised there is an error with the author list on page 8257. The author "Stefanos Kachris" "should read "Stefanos Kachris ${ }^{1,2} "$.

The authors apologize for this error.

\section{Publish your work in this journal}

Cancer Management and Research is an international, peer-reviewed open access journal focusing on cancer research and the optimal use of preventative and integrated treatment interventions to achieve improved outcomes, enhanced survival and quality of life for the cancer patient. The manuscript management system is completely online and includes a very quick and fair peer-review system, which is all easy to use. Visit http://www.dovepress.com/testimonials.php to read real quotes from published authors. 